\title{
High Voltage Electron Microscopic Image of Red Blood Cell in the Blood Vessel of Mouse Brain
}

\author{
Im Joo Rhyu ${ }^{1,2, *}$ \\ ${ }^{1}$ Department of Anatomy, Korea University College of Medicine, Seoul 02841, Korea \\ ${ }^{2}$ Division of Brain Korea 21 Plus Program for Biomedical Science, Korea University College of Medicine, Seoul 02841, Korea
}

*Correspondence to:

Rhyu IJ,

Tel: +82-2-2286-1149

Fax: +82-2-929-5696

E-mail: irhyu@korea.ac.kr

Received June 22, 2017

Revised June 22, 2017

Accepted June 30, 2017

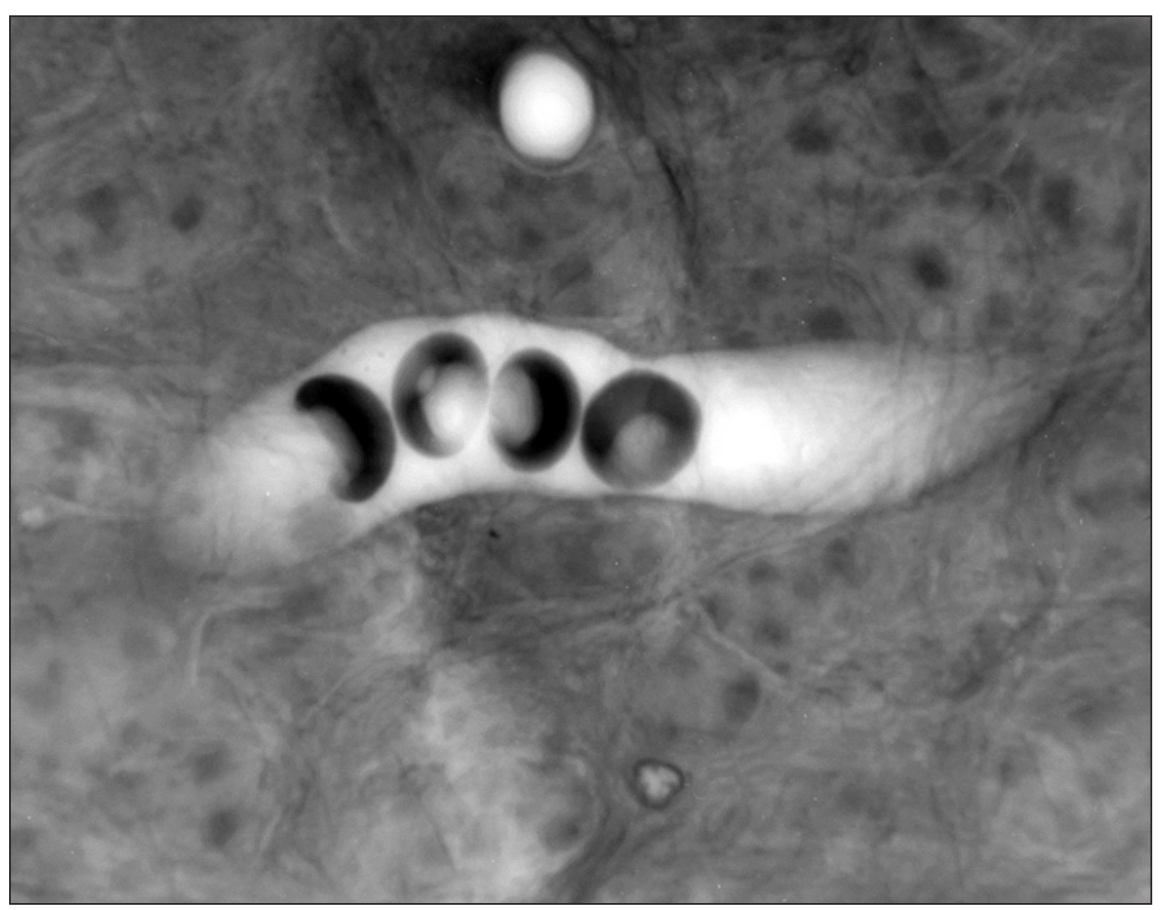

Red blood cells (RBCs) are a major component of blood. They have a characteristic biconcave disc shape, with an edge that is thicker than the center of the cell. This provides a surface area that facilitates the movement of gases in and out of the cells. The diameter of human RBCs is $7.6 \mu \mathrm{m}$ and that of mice RBCs is $6 \mu \mathrm{m}$, with a thickness of $2 \mu \mathrm{m}$, and these dimensions are used as an internal scale for histologic interpretation. The figure shows RBCs inside a mouse brain capillary. The sample was originally prepared to study neuronal cytology using the rapid Golgi method (Oda et al., 2010) for observation under a high-voltage electron microscope (Hitachi H-1250M; Japan) at 2,000× magnification, which enables the analysis of sections of up to $3 \sim 4 \mu \mathrm{m}$ thickness. RBCs, at different angles to the electron beam transmission route, were captured through the window of their thin central area. The electron beam interaction with the peripheral rim of RBCs provided a dark image due to poor electron transmission, whereas the central area was bright. A similar result was reported for an RBC image using a soft X-ray microscope (Kwon et al., 2008). This image demonstrates the characteristic morphology of RBCs and the principles of transmitted electron microscopy. Furthermore, this unique imaging system could potentially be used for analysis of pathological conditions of RBCs (Buys et al., 2013).

(a) This is an open-access article distributed under the terms of the Creative Commons Attribution Non-Commercial License (http://creativecommons.org/licenses/by-nc/4.0) which permits unrestricted noncommercial use, distribution, and reproduction in any medium, provided the original work is properly cited.

Copyrights @ 2017 by Korean Society of Microscopy 


\section{CONFLICT OF INTEREST}

No potential conflict of interest relevant to this article was reported.

\section{REFERENCES}

Buys A V, Van Rooy M J, Soma P, Van Papendorp D, Lipinski B, and Pretorius E (2013) Changes in red blood cell membrane structure in type 2 diabetes: a scanning electron and atomic force microscopy study. Cardiovasc. Diabetol. 12, 25.

Kwon Y M, Kim H K, Kim K W, Kim S H, Yin H H, Chon K S, Kang S H, Park S H, Juhng S K, and Yoon K H (2008) Cellular imaging of gold nanoparticles using a compact soft X-ray microscope. Korean $\mathrm{J}$. Microsc. 38, 235-243.
Oda S I, Lee K J, Arii T, Imoto K, Hyun B H, Park I S, Kim H, and Rhyu I $J$ (2010) Differential regulation of Purkinje cell dendritic spines in rolling mouse Nagoya (tg/tg), P/Q type calcium channel $(\alpha 1(\mathrm{~A}) /$ $\mathrm{Ca}(\mathrm{v}) 2.1)$ mutant. Anat. Cell Biol. 43, 211-217. 